\title{
Enhancing Essential Skills in Basic Education for Sustainable Future: Case Analysis with Exemplars Related to Local Wisdom
}

\author{
${ }^{1 s t *}$ Khar Thoe NG, ${ }^{2 n d}$ Phaik Lah KIM, ${ }^{3 r d}$ Yoon Fah LAY, \\ 4th Yee Jiea PANG, ${ }^{5 \text { th }}$ Eng Tek ONG \& ${ }^{6 \text { th }}$ Subuh ANGGORO \\ \{lesmatpjtsubmission@gmail.com ${ }^{1 *}$,kimp19988@gmail.com², \\ layyf@ums.edu.my ${ }^{3}$, yeejiea@gmail.com ${ }^{4}$, ong.engtek@fpm.upsi.edu.my ${ }^{5}$, \\ subuhanggoro@ump.ac.id $\left.{ }^{6}\right\}$ \\ ${ }^{1 *}$ Training \& Research Division, SEAMEO RECSAM, 11700 Gelugor, Penang, \\ Malaysia \\ ${ }^{2}$ Life Rhythm Sdn. Bhd. (746251-D) previous known as Vision Academy (M) \\ Sdn. Bhd., Georgetown, Penang, Malaysia \\ ${ }^{3}$ Faculty of Psychology and Education, Universiti Malaysia Sabah, 88400 Kota \\ Kinabalu, Sabah, Malaysia \\ ${ }^{4}$ Institute of Technology Management and Entrepreneurship, Universiti Teknikal \\ Malaysia, Melaka, Malaysia \\ ${ }^{5}$ Faculty of Human Development, Sultan Idris Education University, Tanjung \\ Malim, Malaysia \\ ${ }^{6}$ Preservice Elementary Teacher Study Program, Universitas Muhammadiyah \\ Purwokerto, Purwokerto 53182, Indonesia
}

\begin{abstract}
Supporting a quality basic education incorporating the $21^{\text {st }}$ century curriculum to reach out to all including the marginalized groups has been a key priority globally including SEAMEO regions, especially for the past few decades. However, in the advent of the digital era with plentiful resources accessible from a multitude of blended-mode platforms, there are countries with limited resources such as accessibility to Internet connection still facing the problems to access to quality education. Attempts were made to meet the aspirations of Education for All (EFA) and Sustainable Development Goals (SDGs) over the past few decades through basic education reform. This article aims at analyzing the historical revolution of implementation of basic education for the past 2 decades, examine effective strategies that bridge the digital divide and showcase exemplary practices involving countries with potential local wisdom. Mixed-method design matrix is used involving systematic review, analysis on governmental official documents as well as case analysis through 'Dominant model in qualitative research'. The implementation of basic education as a system-wide approach as well as effective strategies to enhance essential skills in basic education in line with SDGs was analysed using Cross-Case Analysis chronologically over the past more than two decades. Subsequently, Within-Case Analysis was conducted to showcase exemplary practices to integrate local wisdom in the respective educational systems in Cambodia, Malaysia, and Indonesia. This study was able to illustrate the practical significance of all co-authors who are the practitioners organizing the events as reported with research findings as analysed that are worth pondering for them to continue the efforts to organize project-based programmes with the development of basic education based on local wisdom. Most of the output was in line with all the Sustainable Development Goals (SDGs) especially No. 4 (Quality Education), No. 5 (Gender Equality), No. 11 (Sustainable Cities
\end{abstract}


and Communities) and No. 17 (Partnerships for the Goals). Due to the various programmes that were elaborated in this paper being initiated at different points of time as the main constraints faced in terms of time and resources available, only selected cases were reported. Moreover, some of the activities were conducted during 2020 when all the countries were facing the constraints of being unable to conduct on-site events due to pandemic. But the lesson learnt that even robotics competition could also be conducted online raised one question to be pondered, 'should basic education be implemented also based on local wisdom in collaboration with industrial partners to promote work or study from home'? More future research should be conducted to ensure that students acquire values and skills with meaningful lifelong learning to ensure inclusive and quality education is also the focus of SDG4-Education 2030 that emphasizes on lifelong learning approaches.

Keywords: Basic education reform, Local wisdom, Sustainable Development Goals (SDGs), Case analysis

\section{Introduction}

\subsection{Background and Overview}

Basic education is defined somewhat differently by various nations globally. Generally, the development of attitudes, competencies, knowledge and values as common elements and a basis of lifelong learning had been used to define basic education that is revolved around core themes by numerous corporations. For example, pre-primary education was included by some countries as part of basic education (see Department of Foreign Affairs and Trade (DFAT) 2015 [1]).

Supporting a quality basic education incorporating the $21^{\text {st }}$ curriculum to reach out to all including the marginalized groups has been a key priority globally including SEAMEO regions especially for the past few decades. Various efforts were made in the global educational settings through the guide from the implementation of policy framework as reflected in the SEAMEO Education Agenda priority areas No.2 'Addressing barriers to inclusion' and No.7 'Adopting a $21^{\text {st }}$-century curriculum' by SEAMEO Secretariat [2]

However, in the advent of the digital era with plentiful resources accessible from a multitude of blended-mode platforms, there are countries with limited resources such as accessibility to Internet connection still facing the problems to access to quality education. Attempts were made to meet the aspirations of Education for All (EFA), Millennium Development Goals (MDGs) and subsequently Sustainable Development Goals (SDGs) over the past few decades through basic education reform [3]. This article aims at analyzing the historical revolution of implementation of basic education for the past 2 decades, examine effective strategies that bridge the digital divide and showcase exemplary practices involving countries with potential local wisdom.

The subsequent sections review related literature with the framework and problem statements that guide the direction of this study.

\subsection{Review of Related Literature}

1.2.1. Essential (Thinking/Technology/Life) Skills Enhancement and Promotion of Quality Education in Line with SDGs

Education is increasingly seen not only as an agent of providing capacity building platform for human resource development or nation-building but also as an agent of change with the enhancement of thinking skills through values-based education [4], project/problem-based learning [5] and inculcation of essential skills for global citizen irrespective of their ethnic groups, nationality, socio-economic status and living environment or locality. 
Over the past decade, the definition of learning space has become broader with the emergence of digital and non-digital learning tools. Studies were conducted by a group of researchers on how sustainable living could be promoted through the development of blendedmode platforms that focus on three essential skills, i.e., thinking, technology and life skills with sharing of resources in easily accessed e-platforms for cross-cultural learning opportunities [6]. The development of life skills that include entrepreneurial, survival and work skills was also made possible in the advent of the digital era with the accessibility of blended-mode platforms and digital tools. Research on an international benchmarking study such as PISA 2009 involving New Zealand and Malaysia [7] also shed some light on the importance to integrate transdisciplinary studies such as 'Science, Technology, Reading, Engineering, Arts, Mathematics' (STREAM) education to promote quality education in line with SDG No. 4.

1.2.2. Values-based Sustainable Education (VaBSE) and Global Citizenship Education (GCED) that Enhance Students' Motivation to Master Essential Skills

In developing countries such as in the South Asia region, there are three main roles of basic education, i.e., to drive economic growth, lessen poverty and minimize inequality. Hence, in order for all global citizens to have a good quality of life, education is an essential need [8] along with other basic needs such as air and water. Realizing such crucial needs in human's life, the Human Values-based Water, Sanitation and Hygiene Education (HVWSHE) was initiated by SEAMEO in collaboration with UN-HABITAT [9] to promote values-based sustainable education through teaching and learning activities related to water education.

Since then, regional and national 'Training of Trainers' events for HVWSHE with subsequent Research and Development (R\&D) activities were conducted and such initiatives were echoed by practitioners through cycles of reflective practices to implement teaching and learning activities in the classroom and school levels [10]. It is hoped that through these activities, learners were instilled with attitude, behaviours, and values with innovation as well as the commitment to human rights, peace and sustainable development that support responsible global citizenship in line with the aspirations of Global Citizenship Education (GCED) [11].

To reduce inequality in education, students of both genders in all localities, whether in urban or rural areas should be motivated to participate in various student-centred learning programmes incorporating essential skills in basic education to achieve their life goals. Psychologists believe that a student's motivation to learn is influenced by a number of values/beliefs, interests and attitudes that can be positive or negative in their effects. Highly positively motivated students would believe that the task is of value (value beliefs), also with high expectations that they would achieve success (expectancy and self-efficacy beliefs) [12].

\subsection{Problem Statement and Rationale}

Over the past few decades, there were various arguments about the types and effectiveness of basic education programmes globally in the population scattering around the far-flung region of each continent. For example, it was found that project-based interventions are generally not sustainable. Whereas suggestion was made that effective, country-led approaches with systemwide support for basic education reform could result in more transformative change. Apart from considering the aspects of accessibility, efficiency, equity and quality of education, there are four main areas to be considered by Ministries of Education. These include: (1) the management of the institution and human resource development database (e.g., with data on deployment, experience, qualification and record of teacher's professional development); (2) budging/fiscal management systems that include operational, policy and strategic planning; (3) evaluation and research activities that are able to analyse the priorities and success in education with availability of system monitoring including an accurate and robust Education Management Information System (EMIS) 
(e.g., with statistics on schools, teachers and students with their learning performance); (4) Communications systems that include ICT infrastructure [3].

Disparity and inequality continue to be topics of discussion over the past few decades. Studies showed that at the primary level, most of the Western Asia and African countries still had $37 \%$ of disparity with female schooling age children from the poorest families were among the highest groups who did not enter a classroom. Other limiting factors that exclude children from basic education opportunities included disability, displacement of refugees, ethnicity, language, rural living areas to name a few as reported in UNESCO 2016a [13]. What's more with the rapid development of Information and Communication Technology that is only available in certain communities but not for others. With the interruptions of various unprecedented events such as the impact of natural disasters [13] and the outbreak of pandemic that needs the attention of human and financial resources in all affected countries, the penetration rate of basic education incorporating technology-enhanced learning is also questionable.

In fact, the efforts made to enhance essential skills in basic education should start from the early years to prevent potential dropouts from the educational systems. Studies also showed that the inclination of secondary school learners' interests to pursue further education, as well as their aspirations in their career choice, had been very much dependent on the opportunities given in education as reported by Zainal et al. [14]. However, studies, as reported in UNESCO 2016b [15], revealed that there was a slowing of universal enrolment with the last $9 \%$ of out-of-school primary children were still being denied of their basic human right to education, hence greatly limiting their future opportunities.

Various global efforts were made to set plans with the allocation of resources to eliminate the disparities in basic education. An example is The World Inequality Database on Education (WIDE) which helped to identify marginalised and vulnerable groups from each country which was published by the Global Education Monitoring Report [16]. In addition, continuing tracking/monitoring and sharing of exemplary practices could also shed some light towards enhancing essential skills in basic education for a sustainable future.

\subsection{Aim and Research Question}

The ultimate aim of this article is to analyze the historical revolution of implementation of basic education for the past 2 decades, examine effective strategies that bridge the digital divide and showcase exemplary practices involving countries with potential local wisdom.

The research questions that underpinned this study were:

(1) How was basic education being implemented as a system-wide approach over the past 3 decades?

(2) What are the effective strategies for the implementation of basic education for a sustainable future?

(3) Are there exemplary practices that could showcase the integration of local wisdom in the educational system of the countries?

\section{Method}

This article reports on the authors' experiences in enhancing essential skills of Basic Education among the youths in the SEAMEO region through various national and international programmes over the past few decades. 'Mixed-method design matrix' is used involving systematic review, analysis on governmental official documents as well as case analysis through 'Dominant model in qualitative research' [17][18]. Using 'Type 4' multiple-case design, mixedmode of data analysis with embedded multiple units of analysis [19] of data collected from interviews, observation and documentary analysis were implemented. This paper examines how 
basic education was implemented the essential elements of effective implementation strategies as well as exemplary cases that fulfilled SDGs.

A systematic review [20][21] was first conducted by selecting literature through numerous databases involving evaluation/synthesis of all available evidence. Whereas a case study is a variation of an ethnography in that the researcher provides an in-depth exploration of a bounded system (e.g., an activity, an event, a process or an individual) based on extensive data collection [22][23]. Web-based service providers and search engines e.g., Research Gate, Google Scholar and Scopus were also used including various studies published in indexed/peer-reviewed e-journals, e-books/online databases such as the International Journal of Computer Applications (IJCA); LearnTechLib; Open Praxis; to name a few. between 2000 to 2019. These include topics or keywords i.e., 'Basic Education, project-based activities, programme-based learning, transdisciplinary studies, STEM, congress, scientific/technology investigative projects, robotics', to name a few.

The papers being selected through systematic review were scrutinized and summarized in tables using mixed-mode of qualitative/quantitative research methods on the content that were in line with the Research Questions. Tables were also used to summarize the analysis of findings from 'Cross Case Analysis' (CCA) that looks for essential elements between the category characteristics or common patterns to use integration mechanisms [24] and Within-Case Analysis (WCA) that elaborates/examines each particular case independently [25]. In this research, the essential skills in basic education are examined through CCA with its implementation of national/international programmes being traced over the past few decades. Whereas selected country-based cases are exemplified through WCA with a critical review or in-depth elaboration of the revolution of basic education reform in terms of policy or planning of the implementation of wide-scale or system-wide programmes that enhance essential skills in basic education $[1][2][3]$.

\section{Result and Discussion}

This section provides in-depth discussions with the illustration of cases in response to Research Questions (RQ) 1 to 3.

\subsection{Implementation of Basic Education as System-Wide Approach in Chronological Order}

Since 1997, the SEAMEO Regional Centre for Education in Science and Mathematics (RECSAM) implemented the 'Search for SEAMEO Young Scientists' regional programme involving secondary school students in 10 SEAMEO member countries as a system-wide approach to introduce basic education. The Centre also worked closely with a local partner Universiti Sains Malaysia (USM) in which the second co-author was the Director of Basic Education Research Unit (BERU) that also promoted project-based programmes, one of which is 'School Industry Programme Initiative' (SIPI). In the advent digital era, ICT integration was introduced as the whole of system communication and official websites were set up to promote elearning and blended learning to reach out to a wider audience in the SEAMEO region and beyond. Among the portals developed included the 'Southeast Asia Regional Capacity-Enhancement Hub' (SEARCH) [26] in the first 12 years' period from 1997 to 2008 as well as 'Learning Science and Mathematics Together' in a Borderless World [LeSMaT(Borderless)] [21] starting 2015.

The following Table 1 summarizes cross-case analysis on the system-wide programme-based learning related to basic education implementation from 1997 to 2008, and 2009 to 2020 respectively. 
Table 1. Cross-Case Analysis on Implementation of Basic Education in System-Wide Programme-based Learning in Chronological Order

\begin{tabular}{|c|c|c|c|c|}
\hline \multirow{2}{*}{$\begin{array}{l}\text { 12-Years' period } \\
\text { (Institution based) }\end{array}$} & \multicolumn{2}{|c|}{1997 to 2008} & \multicolumn{2}{|c|}{2009 to 2020} \\
\hline & Regional Centre & University-based & Regional Centre & University-linked \\
\hline $\begin{array}{l}\text { System-wide } \\
\text { programme- } \\
\text { based } \\
\text { management }\end{array}$ & $\begin{array}{c}\text { 'Search for } \\
\text { SEAMEO } \\
\text { Young } \\
\text { Scientists' } \\
\text { (SSYS) regional } \\
\text { programme }\end{array}$ & $\begin{array}{l}\text { 'School Industry } \\
\text { Programme } \\
\text { Initiative' } \\
\text { (SIPI)(till 2000), } \\
\text { Basic Education } \\
\text { Research Unit } \\
\text { (BERU) }\end{array}$ & $\begin{array}{l}\text { SSYS; and } \\
\text { 'Learning } \\
\text { Science and } \\
\text { Mathematics' in a } \\
\text { Border-less } \\
\text { World' } \\
\text { [LeSMaT } \\
\text { (Borderless)] }\end{array}$ & $\begin{array}{l}\text { UMS Special Fund } \\
\text { Research } \\
\text { Scheme: Grant } \\
\text { Modules for Rural } \\
\text { Primary Schools; and } \\
\text { 'Robotics Competition- } \\
\text { based Learning' } \\
\text { (R-CBL) }\end{array}$ \\
\hline $\begin{array}{l}\text { Target group } \\
\text { (human } \\
\text { development) }\end{array}$ & $\begin{array}{c}\text { Secondary } \\
\text { School teachers } \\
\text { and students in } \\
10 \text { countries }\end{array}$ & $\begin{array}{l}\text { School teachers and } \\
\text { students in } \\
\text { underpriviledged } \\
\text { areas locally }\end{array}$ & $\begin{array}{l}\text { School teachers } \\
\text { and students in } \\
11 \text { countries }\end{array}$ & $\begin{array}{l}\text { Primary school } \\
\text { teachers and pupils at } \\
\text { rural schools in Sabah } \\
\text { and schools interested } \\
\text { in the robotics } \\
\text { competition }\end{array}$ \\
\hline $\begin{array}{l}\text { Policy/ strategic/ } \\
\text { operational } \\
\text { planning }\end{array}$ & $\begin{array}{l}\text { Five-year } \\
\text { development } \\
\text { and strategic } \\
\text { plans were } \\
\text { prepared for } \\
\text { each phase of } \\
\text { R\&D activities } \\
\text { involving the } \\
\text { SSYS regional } \\
\text { programme. }\end{array}$ & $\begin{array}{l}\text { (1) BERU, USM } \\
\text { collaborating with } \\
\text { (2) Human Resource } \\
\text { Division of Penang } \\
\text { State Government; } \\
\text { (3) Penang } \\
\text { Education } \\
\text { Department; (4) Free } \\
\text { Trade International } \\
\text { Industrial } \\
\text { Cooperation. }\end{array}$ & $\begin{array}{l}\text { Five-year } \\
\text { development and } \\
\text { strategic plans } \\
\text { were prepared for } \\
\text { each phase of } \\
\text { R\&D activities } \\
\text { involving SSYS } \\
\text { and LeSMaT } \\
\text { regional } \\
\text { programmes. }\end{array}$ & $\begin{array}{l}\text { Two-year research } \\
\text { project under UMS } \\
\text { Special Fund Research } \\
\text { Grant Scheme } \\
\text { (SDK0026-2018), } \\
\text { Two- year robotics } \\
\text { research project under } \\
\text { the collaboration of } \\
\text { primary schools, } \\
\text { secondary schools and } \\
\text { UTeM in the } \\
\text { International Robotics } \\
\text { Competition.[44][45] }\end{array}$ \\
\hline $\begin{array}{l}\text { System } \\
\text { monitoring, } \\
\text { evaluation and } \\
\text { research }\end{array}$ & $\begin{array}{l}\text { An evaluation of } \\
\text { scientific } \\
\text { creativity and } \\
\text { problem-solving } \\
\text { behaviours of } \\
\text { SSYS } \\
\text { delegates was } \\
\text { made [27] }\end{array}$ & $\begin{array}{l}\text { The organisation of } \\
\text { activities such as } \\
\text { carnival, workshop, } \\
\text { camp, etc. to } \\
\text { monitor, evaluate } \\
\text { and conduct R\&D } \\
\text { activities. }\end{array}$ & $\begin{array}{l}\text { An online } \\
\text { learning hub in } \\
\text { SEARCH for } \\
\text { youth science and } \\
\text { mathematics } \\
\text { researchers [26] } \\
\text { as well as other } \\
\text { hyperlinks } \\
\text { websites and e- } \\
\text { forums. }\end{array}$ & $\begin{array}{l}\text { Integration of } 5 \mathrm{E} \\
\text { (Engagement, } \\
\text { Exploration, } \\
\text { Explanation, } \\
\text { Elaboration, } \\
\text { Evaluation) } \\
\text { instructional model in } \\
\text { enhancing rural } \\
\text { primary and secondary, } \\
\text { school students' } \\
\text { knowledge and } \\
\text { attitudes towards } \\
\text { learning STEM [46] }\end{array}$ \\
\hline $\begin{array}{l}\text { The whole of } \\
\text { system } \\
\text { communication } \\
\text { including ICT } \\
\text { infrastructure }\end{array}$ & $\begin{array}{l}\text { SSYS website } \\
\text { hyperlinked to } \\
\text { SEARCH [26] } \\
\text { portal }\end{array}$ & $\begin{array}{l}\text { Setting up of e- } \\
\text { learning website for } \\
\text { schools }\end{array}$ & 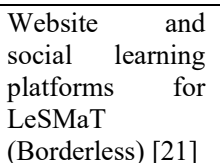 & $\begin{array}{l}\text { STEM integrated } \\
\text { teaching and learning } \\
\text { modules r using } \\
\text { Robotics as a tool [47] }\end{array}$ \\
\hline
\end{tabular}




\subsection{Effective Strategies to Enhance Essential Skills in Basic Education in Line with Sustainable Development Goals (SDGs)}

Section 3.1 elaborated on how basic education was implemented as a system-wide approach chronologically within 12 years' periods from 1997 to 2008 and 2009 to 2020 respectively. The section will illustrate how effective strategies were implemented to enhance essential skills in basic education in line with Sustainable Development Goals (SDGs). Apart from the SIPI programme that was implemented by BERU aiming to promote the values-based initiative for deprived schools mainly for industry-technology driven activities towards the advanced country in the first 12 years' period, the modular approach to teach STEM also aimed at enhancing literacy and local wisdom of primary learners in rural schools using various low-cost teaching aids as the most recently introduced university-linked system-wide programme.

In the advent of the digital era, the blended-mode activities were also conducted aiming at enhancing essential skills. A blended-mode robotics competition was also conducted in 2020 using a virtual platform due to a pandemic that caused the inability to conduct this event that was used to be an on-site event.

The following Table 2 summarizes a cross-case analysis on efforts made by regional centres and universities to incorporate strategies for enhancing essential skills in basic education that are in line with Sustainable Development Goals (SDGs).

Table 2. Cross-Case Analysis on Strategies to Enhance Essential Skills in Basic Education in Line with SDGs following Chronological Order

\begin{tabular}{|c|c|c|c|c|}
\hline \multirow{2}{*}{$\begin{array}{c}\text { 12-Years' } \\
\text { period (Strategies) }\end{array}$} & \multicolumn{2}{|c|}{1997 to 2008} & \multicolumn{2}{|c|}{2009 to 2020} \\
\hline & Regional Centre & University-based & Regional Centre & University-linked \\
\hline $\begin{array}{l}\text { System-wide } \\
\text { project-based } \\
\text { programme }\end{array}$ & $\begin{array}{l}\text { 'Search for SEAMEO } \\
\text { Young Scientists' } \\
\text { (SSYS) regional } \\
\text { programme }\end{array}$ & $\begin{array}{c}\text { 'School Industry } \\
\text { Partnership } \\
\text { Initiative' } \\
\text { (SIPI), Basic } \\
\text { Education Research } \\
\text { Unit (BERU) }\end{array}$ & $\begin{array}{l}\text { 'Learning Science and } \\
\text { Mathematics' in a } \\
\text { Border-less World' } \\
\text { [LeSMaT (Borderless)] }\end{array}$ & $\begin{array}{l}\text { STEM-Module for Rural } \\
\text { Primary School; and } \\
\text { 'Robotics Competition- } \\
\text { based Learning' } \\
\text { (R-CBL) }\end{array}$ \\
\hline $\begin{array}{l}\text { Thinking skills } \\
\text { enhancement }\end{array}$ & $\begin{array}{c}\text { Thinking } \\
\text { (Mathematics and } \\
\text { Science learning) } \\
\text { skills }\end{array}$ & $\begin{array}{c}\text { Modular } \\
\text { approach to enhance } \\
\text { thinking (scientific } \\
\text { thinking/ PBL) skills }\end{array}$ & $\begin{array}{c}\text { Thinking (e.g., Decision } \\
\text { making) skills }\end{array}$ & $\begin{array}{l}\text { Higher Order Thinking } \\
\text { Skills (HOTs) and } \\
\text { Computational Thinking } \\
\text { Skills }\end{array}$ \\
\hline $\begin{array}{l}\text { Technology } \\
\text { skills integration }\end{array}$ & $\begin{array}{l}\text { Web-based learning in } \\
\text { a blended-mode } \\
\text { platform }\end{array}$ & $\begin{array}{l}\text { Computer literacy e- } \\
\text { learning skills with } \\
\text { handphones being } \\
\text { sponsored }\end{array}$ & $\begin{array}{l}\text { Study skills for Open and } \\
\text { Distant Learning }\end{array}$ & $\begin{array}{l}\text { STEM integrated } \\
\text { teaching and learning at } \\
\text { rural primary and } \\
\text { secondary schools }\end{array}$ \\
\hline $\begin{array}{l}\text { Life skills } \\
\text { inculcation }\end{array}$ & $\begin{array}{l}\text { Life (e.g., } \\
\text { participation in Co- } \\
\text { curriculum) skills }\end{array}$ & $\begin{array}{l}\text { Life (especially } \\
\text { workplace } \\
\text { communication) } \\
\text { skill using English } \\
\text { language facilitated } \\
\text { by factory (industrial } \\
\text { partner). }\end{array}$ & $\begin{array}{l}\text { Life (e.g., learning/ } \\
\text { writing/ } \\
\text { skills }\end{array}$ & $\begin{array}{l}\text { Contextual based } \\
\text { teaching and learning at } \\
\text { rural primary and } \\
\text { secondary schools }\end{array}$ \\
\hline $\begin{array}{l}\text { Values-based } \\
\text { Sustainable } \\
\text { Education } \\
\text { (VaBSE) }\end{array}$ & $\begin{array}{l}\text { Water and Values } \\
\text { Education (WAVE) } \\
\text { or HVWSHE [9] }\end{array}$ & $\begin{array}{l}\text { Values-based } \\
\text { initiative for } \\
\text { deprived schools } \\
\text { mainly for industry- } \\
\text { technology driven } \\
\text { activities towards an } \\
\text { advanced country }\end{array}$ & $\begin{array}{l}\text { VaBSE [28] as subtheme } \\
\text { in Edmodo social } \\
\text { learning }\end{array}$ & $\begin{array}{l}\text { Contextual based } \\
\text { teaching and learning at } \\
\text { rural primary and } \\
\text { secondary schools }\end{array}$ \\
\hline $\begin{array}{l}\text { Global } \\
\text { Citizenship } \\
\text { Education } \\
\text { (GCED) }\end{array}$ & $\begin{array}{lr}\text { Human rights } \\
\text { awareness r is } \\
\text { incorporated in the } \\
\text { WAVE module }\end{array}$ & $\begin{array}{l}\text { Human rights } \\
\text { awareness including } \\
\text { access and equity in } \\
\text { education }\end{array}$ & $\begin{array}{l}\text { Human rights awareness } \\
\text { is incorporated in } \\
\text { modules }\end{array}$ & $\begin{array}{l}\text { Human rights awareness } \\
\text { is incorporated in } \\
\text { modules }\end{array}$ \\
\hline
\end{tabular}




\subsection{Exemplary Practices that Showcase Integration of Local Wisdom in the Respective Educational System}

Analysis of historical development of institutions revealed that the types of project-based programmes were revolved from purely on-site during the conduct of events [e.g., 'Search for SEAMEO Young Scientists' (SSYS) regional congress] to blended-mode integrating technologyenhanced learning digital tools and e-platforms [e.g., 'Learning Science and Mathematics Together' in a borderless world or LeSMaT(Borderless)]. This is reflected in Table 3 that summarizes a within-case analysis on exemplary practices in the selected system-wide programme(s) implemented by the Regional Centre and university. Subsequently, elaboration will be made on four case exemplars related to the integration of local wisdom in project-based activities (PBA) presented by SSYS delegates from Cambodia and Malaysia.

Table 3. Within-Case Analysis on Exemplary Practices in Selected System-Wide Programme(s) following Chronological Order

\begin{tabular}{|c|c|c|c|c|c|}
\hline \multirow{2}{*}{$\begin{array}{c}\text { Case/ } \\
\text { Exemplar }\end{array}$} & \multicolumn{2}{|c|}{ Strategies/Approaches } & \multicolumn{2}{|l|}{ Essential } & \multirow{2}{*}{$\begin{array}{l}\text { Enhancement } \\
\text { Life }\end{array}$} \\
\hline & Local wisdom & PBL/VaBSE & Thinking & Technology & \\
\hline $\begin{array}{l}\text { SSYS system- } \\
\text { wide project- } \\
\text { based } \\
\text { programme } \\
\text { (Selected } \\
\text { projects from } \\
\text { Cambodia and } \\
\text { Malaysia) }\end{array}$ & $\begin{array}{c}\text { Identification } \\
\text { of } \mathrm{NaHSO}_{3} \text { testing } \\
\text { on bean [29], } \\
\text { Penang Nutmeg } \\
\text { project [30] and } \\
\text { Prawn pond } \\
\text { sludge as an } \\
\text { organic fertilizer } \\
{[31]}\end{array}$ & $\begin{array}{l}\text { A composite } \\
\text { organic filter to } \\
\text { combat water } \\
\text { pollution [32] in } \\
\text { SSYS 2006 [33] }\end{array}$ & $\begin{array}{l}\text { Scientific thinking } \\
\text { skills in } \\
\text { experimentation and } \\
\text { investigation. } \\
\text { Higher-order (critical/ } \\
\text { creative) thinking [34] }\end{array}$ & $\begin{array}{l}\text { Application of } \\
\text { science concepts } \\
\text { (e.g., Chemistry, } \\
\text { Biology) in daily } \\
\text { life (agriculture, } \\
\text { combating } \\
\text { pollution, etc.) } \\
{[35]}\end{array}$ & $\begin{array}{l}\text { Communication skills in } \\
\text { documenting experimental } \\
\text { results, preparing research } \\
\text { reports, disseminating } \\
\text { findings, etc. [36] as part of } \\
\text { public science education [37] }\end{array}$ \\
\hline $\begin{array}{l}\text { SIPI system- } \\
\text { wide } \\
\text { programme }\end{array}$ & $\begin{array}{l}\text { Human resource } \\
\text { support to } \\
\text { enhance local } \\
\text { wisdom from } \\
\text { industries }\end{array}$ & $\begin{array}{l}\text { Project-based } \\
\text { learning module } \\
\text { incorporating } \\
\text { values [34] }\end{array}$ & $\begin{array}{c}\text { Scientific and } \\
\text { problem-solving skills } \\
\text { during project-based } \\
\text { learning }\end{array}$ & $\begin{array}{l}\text { Basic computer } \\
\text { literacy with } \\
\text { hands-on e- } \\
\text { learning }\end{array}$ & $\begin{array}{l}\text { Life (work/ communication) } \\
\text { skills among students of low } \\
\text { socio-economic status (SES) }\end{array}$ \\
\hline $\begin{array}{l}\text { LeSMaT } \\
\text { (Borderless) } \\
\text { system-wide } \\
\text { programme } \\
\text { (Indonesia \& } \\
\text { Malaysian) }\end{array}$ & $\begin{array}{l}\text { Learning output } \\
\text { reflecting local } \\
\text { wisdom (e.g., } \\
\text { ASEAN } \\
\text { landmark using } \\
\text { AR tools by } \\
\text { Indonesian } \\
\text { delegate [38] }\end{array}$ & $\begin{array}{l}\text { Learners' output } \\
\text { integrating } \\
\text { Values-based } \\
\text { Sustainable } \\
\text { Education } \\
\text { (VaBSE) in } \\
\text { LearnT- } \\
\text { SMArET [39] }\end{array}$ & $\begin{array}{l}\text { Scientific, higher-order } \\
\text { and problem-solving } \\
\text { skills during project- } \\
\text { based activities (PBA) } \\
\text { and problem-based } \\
\text { learning (PBL) }\end{array}$ & \begin{tabular}{l}
\multicolumn{2}{l}{ Application of } \\
science concepts \\
(e.g., Biology, \\
Health Science) \\
using Augmented \\
Reality (AR) tools
\end{tabular} & $\begin{array}{l}\text { Communication skills in } \\
\text { documenting experimental } \\
\text { results, preparing research } \\
\text { reports, disseminating } \\
\text { findings, publishing, etc. }\end{array}$ \\
\hline $\begin{array}{l}\text { STEM module } \\
\text { for primary and } \\
\text { secondary } \\
\text { schools using } \\
\text { 'Robotics } \\
\text { Competition- } \\
\text { based Learning' } \\
\text { (R-CBL) } \\
\text { (Malaysian) }\end{array}$ & $\begin{array}{l}\text { Optimization of } \\
\text { locally available } \\
\text { teaching } \\
\text { materials for } \\
\text { teaching and } \\
\text { learning to } \\
\text { promote } \\
\text { integrated } \\
\text { STEM } \\
\text { curriculum }\end{array}$ & $\begin{array}{l}\text { Contextual } \\
\text { based teaching } \\
\text { and learning at } \\
\text { rural primary } \\
\text { schools }\end{array}$ & $\begin{array}{l}\text { Higher } \\
\text { Thinking } \\
\text { (HOTs) }\end{array}$ & $\begin{array}{l}\text { Blended-mode } \\
\text { and fully } \\
\text { online } \\
\text { during pandemic }\end{array}$ & $\begin{array}{l}\text { Communication skills in } \\
\text { documenting experimental } \\
\text { results, preparing research } \\
\text { reports, disseminating } \\
\text { findings, publishing, etc }\end{array}$ \\
\hline
\end{tabular}

SEAMEO ministries of education have set long term plans for basic education quality improvements' programmes since the inception of SEAMEO in 1965. Like many other countries, the Ministry of Education, Youth and Sport in Cambodia identified strategies to improve the quality and efficiency of education for all school-age children. For example, the Education 
Strategic Plan 2014-18 focuses on strengthening the quality of and access to a comprehensive nine-year program of basic education involving an effective quality framework, Child-Friendly Schools approach with a protective learning environment, curriculum reform, improved teaching practices as well as learning assessment system that linked to curriculum standards and various teacher development programmes [40]. The country's participation in student-centred learning programmes with the presentation in events such as SSYS regional congress also started since the first SSYS that was conducted in 1997. An exemplary students' investigative project that showcases the application of local wisdom can be seen in the output of the project team led by Chroeng and Hean [29]. Students used their own wisdom to apply what they learnt in Chemistry to identify the harmful effect on human health by Sodium Bisulfite $\left(\mathrm{NaHSO}_{3}\right)$ that was used as a chemical substance to make agricultural products such as vegetables fresher. They understood that when sodium bisulfite is added to vegetables, it will become white colour and causes an unfavourable effect on human health if the vegetable is consumed. This is because sodium bisulfite has the potential of a violent exothermic reaction, for example, if mixed with acid, sulfur dioxide is liberated with an increased $\mathrm{pH}$. If mixed with strong oxidizing agents upon reaction with other agents, it could yield sodium sulphate as a moderately strong reducing agent. This Cambodian project team presented the findings from their experimental findings on how $\mathrm{NaHSO}_{3}$ was identified through testing on the bean as an example of a vegetable.

The second case exemplar is the Malaysian students' project entitled 'The experiment of Penang nutmeg: It's growth and conditions' by Wong and Chew [30] in which the second coauthor was also one of the project advisors. The project team members were aware that the planting or farming industry of nutmeg (which was a precious local agricultural product before) was diminishing with a lot of old trees were replaced by other agricultural products suitable for a tropical climate such as durian. Using their wisdom they explored the scenario and set their top prioritized research question that guided their investigation as 'Why not planting nutmeg this but shifting crops to durian planting instead? Among their R\&D activities included providing background information; conducting surveys among farmers and consumers to assist in the understanding of causes or factors contributing to the decline of farmer's interest to cultivate nutmeg; creating awareness on the possibility of extinction of this economic activity and proposing solutions to reverse the decline. The project team conducted an experiment to explore if the growing of nutmeg seedlings can be done with different success rates in numerous types of soil conditions. Their experiment also observed and discovered diseases that affected the growth during the stage of seedlings that were divided into two trays with a recording of their growth. A field study was conducted to record the growth stages of nutmeg trees post in stages of about 6 to 8 weeks. Farmers with local wisdom and futuristic thinking were interviewed. The findings revealed that the farmers justified that nutmeg planting had not been productive with low economic value and was replaced by planting durian that needs 20 to 30 years to grow but with more economic values in the long run. The project team also conducted data gathering and documentation of information on the average produce per year, the duration of planting and stages of growth before the first harvest. The project team also identified the Cambial rot problem faced by the farmers by recording their successful efforts to surgically remove the Cambial rot with treatment using fungicide that contains Captafol.

The next two case exemplars related to organic products and environmental conservation are the Malaysian students' projects entitled 'Prawn pond sludge as an organic fertilizer: Phase II' 
by Larry Ellee [31] as well as 'A composite organic filter to combat water pollution' by Muhammad Arif and Muhammad Mursyid [32] respectively. The former project [31] explored the use of pond sludge as a safe organic fertilizer to replace chicken manure for the types of vegetables studied involving local wisdom of the prawn farming industry to grow three-leaf vegetables (Brassica sp.) and tomato (Lycopersicum esculentum) with proper measures adhered to. For example, the prawn pond sludge contains Nitrogen $(1.1 \%)$ and Phosphorus $(0.7 \%)$ for plant growth. Heavy metals (Copper $[\mathrm{Cu}]$, Zinc $[\mathrm{Zn}]$, Cadmium [Cd], Lead $[\mathrm{Pb}]$, Nickel $[\mathrm{Ni}]$, Chromium [Cr]) concentrations of sludge did not exceed the Malaysian Department of Environment (DOE) and European Legislation of maximum permissible level. The concentrations of heavy metals $(\mathrm{Cu}, \mathrm{Zn}, \mathrm{Cd}, \mathrm{Pb})$ in all vegetables did not exceed the maximum permissible level of the Malaysian Food Act.

The organic filter designed by Muhammad Arif and Muhammad Mursyid [32] also complied with the requirements of Malaysian DOE such as suspended solids (SS) and turbidity that were below $40 \mathrm{ppm}$ after the sewage was treated using the composite organic filter they invented. The project team members applied their local wisdom by using economical and plentiful waste materials such as coconut husk fibre, hair and rice husk to build a composite organic adsorbent as well as individual adsorbent that were tested and successfully implemented to combat river pollution by treating wastewater containing grease and oil. Four columns, each containing a different organic filter, were used. The analysis revealed that the percentage of oil adsorbed by coconut husk fibre, hair, rice husks, and the composite adsorbent were found to be $90 \%, 80 \%$, $90 \%$ and $90 \%$ respectively.

The last case exemplar is the implementation of an integrated STEM curriculum through Robotics Competition-based Learning (R-CBL). The objective of this project is to enhance students' learning in STEM subjects and to embed their interests towards STEM [48]. This newly enhanced project was introduced to the primary schools and secondary school educators through the Integrated Robotics STEM Module, as an emerging learning platform to enable students to cope with skills that are essential for success in the 21 st century. This project can strengthen the 21 st century problem-solving and social skills that are critical for success in further studies and future careers including creative and critical thinking, collaborative teamwork skills, interpersonal communication, and problem-solving [49]. There is a total of 8 robotics projects designed in the Integrated Robotics STEM Module. The effectiveness of this module was evaluated using the Robotics Competition-based Learning (R-CBL) framework, which was carried out in the year 2018 and 2019, in the International Robot Olympics Malaysia. During the competition, the educators have focused on the integration of 21st-century competencies in the subject in the scope where robots are deployed on their students [44][50]. The R-CBL is aligned with the STEM integration and the idea of inter-disciplines, which cultivate the higher-order thinking skills while enhancing the students' interest in STEM subjects. As the result, the students who were participated in this project demonstrated their creativity, design ideas and develop problemsolving skills through challenging and educational robotics competitions, such as Robot SUMO, Robot Cleaner, Robot Archer, Robot Racer and Robot Bowler [44][45].

\section{Conclusion}

\subsection{Summary and Implications}


This study was able to illustrate the practical significance of all co-authors who are the practitioners organizing the events as reported with research findings as analysed that are worth pondering for them to continue the efforts to organize project-based programmes with the development of basic education based on local wisdom. Most of the output was in line with all the Sustainable Development Goals (SDGs) especially No. 4 (Quality Education), No. 5 (Gender Equality), No. 11 (Sustainable Cities and Communities) and No. 17 (Partnerships for the Goals). The global developmental priority to educate girls with transformative effects can be reflected in case exemplar No. 2 which was elaborated earlier in which the SSYS project team members consisted of female students' experimentation of the growth and conditions of Penang nutmeg. In fact, many investigative projects presented in SSYS regional congresses were developed based on the local wisdom of the project team members or delegates, many of whom involving female students but not elaborated in this study. The implication of Gender Equality is not just for economic or social aspects, literature also revealed that there were lower rates of infant mortality and malnutrition in countries with more gender-equitable education. [41] While it is vital that countries make additional and special initiative targetting education for female students, these efforts will only work in the context of a wider focus based on universal basic education for all children to reduce the gap of education for students of all gender and locality, i.e., urban and rural areas. [15]

A number of strategies were identified in the educational institutions as an alternative to address the challenges to quality basic education, among which the conversion of delivery mode from fully on-site or face-to-face into blended-mode that involve both on-site and online has been a pertinent approach in the digital era especially during the recent outbreak of a pandemic. All countries globally are encouraged to ensure at least nine years of compulsory education as part of their provision of 12 years of free, publicly funded equitable quality education under the UNESCO 2030 Education Framework for Action [15].

Since project-based programmes incorporating basic education curriculum and local wisdom were proven to be effective with evidence-based findings as reported in this study, an implication that could be pondered is to consider flexible and complementary quality strategies to be pursued. Perhaps some provision of new instructional materials accessible to all families of school-going children should be made more widely accessible with guidance and monitoring from experts. The roles of supervision of learners' output should also be redefined with remedial activities in all years to assist weak learners who are unable to cope with the entire curriculum.

\subsection{Limitations and Suggestions for Future Studies}

This article reports part of the ongoing study to explore how essential skills in basic education could be enhanced and evaluated through innovative pedagogical approaches incorporated in e.g., technology-enhanced project-based programmes sustainably without being affected by any unforeseen circumstances such as the outbreak of pandemic with implications on Human Resource Development (HRD) in line with SDGs that are worth pondering. Due to the various programmes being elaborated in this paper were initiated at different points of time as the main constraints faced in terms of time and resources available, only selected cases were reported through cross-case analysis, within-case and exemplary case analysis. In addition, some of the 
activities were conducted during 2020 when all the countries were facing the constraints of being unable to conduct on-site events due to pandemic.

But one lesson learnt from this study is that even robotics competition could also be conducted online, this raises the question of 'should basic education be implemented also based on local wisdom in collaboration with industrial partners to promote work or study from home'? In fact, all the lessons learnt from various case analyses as reported in this study should be pondered into for more future research to be conducted to ensure that students acquire values and skills with meaningful lifelong learning outcomes that assist them in playing a positive role within their own societies, coping with rapidly changing world as well as contributing to the development and the growth of the economy in their countries. Ensuring inclusive and quality education is also the focus of Sustainable Development Goal 4 (SDG 4) [1]. Hence future research should be more focused on SDG4-Education 2030 that is focused on lifelong learning approaches with efforts to increase and expand access, equity, inclusion as well as outcomes and quality of learning at all levels [15].

Since Human Resource Development (HRD) is very much dependent upon the number and types of citizens who received a basic education and specialized training, efforts to promote their creative ability should be continued ongoingly through values-based technology-enhanced blended-mode programmes that introduce transdisciplinary science education [42] including aspects such as 'Science, Technology, Reading, Engineering, Arts, Mathematics' (STREAM). More efforts should also be made to ensure quality in basic education that include aspects i.e., (1) Child-centred pedagogy with active teaching and learning processes; (3) Curriculum content that is appropriate and relevant to the present and future lives of learners; (4) Learning environments that are supportive, child friendly and of quality; (4) Precise assessment on the quality outcome of learning to inform practice, to obtain an understanding of successes that meet established learning standards as well as challenges faced at the individual, educational settings and national levels; and (5) Quality learners who are healthy and ready-to-learn. [41][43].

\section{Acknowledgements.}

The authors wish to acknowledge internal research grants of SEAMEO RECSAM, information from the Basic Education Research Unit of Universiti Sains Malaysia and special fund grant scheme of Universiti Malaysia Sabah for funding various research projects related to developing local wisdom and eliciting the potentials among students or young researchers from rural areas.

\section{References}

[1] Department of Foreign Affairs and Trade (DFAT). Strategy for Australia's aid investments in education 2015-2020, September, Commonwealth of Australia. Retrieved September 14, 2017 from $\mathrm{http} / / / d f a t . g o v . a u / a b o u t-u s /$ publications/Documents/strategy-foraustralias-aid-investments-ineducation-2015-2020.pdf

[2] SEAMEO. Action Agenda for the SEAMEO 7 Priority Areas. 2018. Bangkok, Thailand: Southeast Asian

Ministers of Education Organization (SEAMEO) Secretariat.

https://www.seameo.org/SEAMEOWeb2/images/stories/Publications/

Centers_Pub/SEAMEO_Education_agenda/Action\%20Agenda\%20for\%20the\%20SSEAMEO

Education Agenda 
[3] DFAT. Basic education: Practitioner level. Australian Government Department of Foreign Affairs and Trade (DFAT). https://www.dfat.gov.au/sites/default/files/basic-education-practitioner-level.docx

[4] Tan, K.A., Leong, C.K. and Ng, K.T. Enhancing mathematics processes and thinking skills in valuesbased water education. Presentation during $3^{\text {rd }}$ CoSMEd 2009. Penang, Malaysia: SEAMEO RECSAM.

[5] Tan, K.A., Ng, K.T., Ch'ng, Y.S., and Teoh, B.T. Redefining mathematics classroom incorporating global project/problem-based learning programme. Presentation during $2^{\text {nd }}$ CoSMEd 2007, $13^{\text {th }}$ to $16^{\text {th }}$ November. Penang, Malaysia: SEAMEO RECSAM.

[6] I Gil-Jaurena and B. Malik. Innovation and best practice in open and distance education. Open Praxis. 5(4). 261-263. https://www.openpraxis.org/index.php/OpenPraxis/article/view/103/68

[7] Conner, L., K.T. Ng, N.J. Ahmad, H.Ab. Bakar, S. Parahakaran and Y.F. Lay. Evaluating students performance for scientific literacy, reading and thinking skills in PISA 2009: Lessons learnt from New Zealand and Malaysia. Paper presented and compiled in proceedings (refereed) of the fifth International Conference on Science and Mathematics Education (CoSMEd) 2013. Penang, Malaysia: SEAMEO RECSAM.

[8] World Bank. Brief on education in South Asia, World Bank. n.d. Retrieved 14 September 2017, http://go.worldbank.org/G22NKEQZP0

[9] $\mathrm{Ng}$, K.T. Integration of human values in HVWSE curriculum incorporating teaching strategies/approaches and assessment/evaluation techniques. In P.Pannen, K.T.Ng, J.Ikhsan, D.Mustafa and Herawati (Eds.). SEAMEO resource package: Human Values-based Water, Sanitation and Hygiene Education (HVWSHE). SEAMEO SEAMOLEC and UN-HABITAT, 2007.

[10] Toh, L. Yeap, C.H., Ng, K.T. and Isma, F. Cross-curricular teaching incorporating human values: A collaborative research by reflective practitioners. In Learning Science and Mathematics (LSM) online journal. 2007;11(2),9-31.

[11] UNESCO. Global citizenship education. 2019. https://en.unesco.org/themes/gced

[12] Lay, Y.F., Ng, K.T. and Chong, P.S. Analyzing affective factors related to eighth grade learners' science and mathematics achievement in TIMSS 2007.The Asia-Pacific Education Researcher. 2015;24(1),103110 ,

[13] UNESCO. Education for people and planet: Creating sustainable futures for all. Global Education Monitoring Report 2016, p.262. 2016a. Retrieved 14 September 2017, http://unesdoc.unesco.org/images/0024/002457/245752e.pdf

[14] G. Zainal, M.J. Haris and K.T. Ng. The Malaysian dropout study revisited. Penang, Malaysia: Basic Education Research Unit, 1991.

[15] UNESCO. Education 2030: Incheon Declaration and Framework for Action for the implementation of Sustainable Development Goal 4 (ED-2016/WS/28), 2016b.

[16] UNESCO Institute for Statistics \& Global Education Monitoring Report n.d., The World Inequality Database on Education. Retrieved 14 September 2017,

[17] J..W.Creswell. Research design: Qualitative, quantitative and mixed methods approaches. $3^{\text {rd }}$ ed. Sage Publications, Inc., 2009.

[18] R.B.Johnson and A.J.Onwuegbuzie. Mixed methods research: A research paradigm whose time has come. Educational Researcher, 33(7), 14-26, Summer, 2004.

[19] R.K.Yin. Case study research design and methods. $5^{\text {th }}$ ed. Thousand Oaks, CA: Sage Publications, 2014. Retrieved January 31, 2021 from URL: https://www.researchgate.net/publication/ 308385754_Robert_K_Yin_2014_Case_Study_Research_Design_and_Methods_5th_ed_Thousand_O aks_CA_Sage_282_pages

[20] Adibah Mohd., A., Corrienna, A.T., Faruku, A., Ng, K.T, Subuh, A. \& Marlia, A. Problem-based Learning (PBL) as an assessment tool in science education: A systematic review with exemplars (pp.102118). In Learning Science and Mathematics (LSM) online journal. Issue 15 December, 2020.

[21] Ng, K.T., B. Baharum, M. Othman, S. Tahir and Y.J.Pang. Managing technology-enhanced innovation programs: Framework, exemplars and future directions. Solid State Technology. 63(1s). 555-565, 2020. 
http://www.solidstatetechnology.us/index.php/JSST/article/view/741

[22] J.W. Creswell. Educational research: Planning, conducting and evaluating quantitative and qualitative research. $2^{\text {nd }}$ ed. Upper Saddle River, New Jersey: Pearson Education, Inc., 2005.

[23] J.W. Creswell. Research design: Qualitative, quantitative and mixed methods approaches. $3^{\text {rd }}$ ed. Sage Publications, Inc., 2009.

[24] K.M.Eisenhardt. Building theories from case study research. Academy of Management Journal, 32(3), 543-576, 1989

[25] R.K.Yin. Case study methods (Rev..ed.). Thousand Oaks, CA: Sage Publications, 2004.

[26] Ng, K.T. and Nyunt, K.A.K. The development of an online learning hub in SEARCH for youth science and mathematics researchers. In Z. Abas and J. Luca (Eds.), Proceedings of Global Learn Asia Pacific 2010- Global Conference on Learning and Technology (pp.1158-1167)(LearnTechLib). Penang, Malaysia: Association for the Advancement of Computing in Education (AACE).

[27] Ng, K.T. An evaluation of the scientific creativity and problem-solving behaviours of young learners in the development of investigative project work. Presentation compiled in the refereed proceeding for the $1{ }^{\text {st }}$ CoSMEd 2005 Penang, Malaysia: SEAMEO RECSAM.

[28] Ng, K.T., Parahakaran, S., Febro, R., Weisheit, E. and Lee, T.L. Promoting sustainable living in the borderless world through blended learning platforms. Open Praxis. 5(4), 275-288. Nov 26, 2013. Publisher: International Council for Open and Distance Education (ICDE).

[29] Chroeng S. and Hean L. Identification of Sodium Bisulphite $\left(\mathrm{NaHSO}_{3}\right)$ testing on bean. (Chapter 4, pp.49-56). In K.T.Ng (Ed.). Selected student research projects of the $5^{\text {th }}$ Search for SEAMEO Young Scientists (SSYS 2006) Congress. 20 Penang, Malaysia: SEAMEO RECSAM, 2012.

[30] Wong, W.M. and Chew W.J. The experiment of Penang nutmeg: Its growth and conditions. (Chapter 11, pp.178-188). In K.T.Ng (Ed.). Selected student research projects of the $5^{\text {th }}$ Search for SEAMEO Young Scientists (SSYS 2006) Congress. 20 Penang, Malaysia: SEAMEO RECSAM, 2012.

[31] Larry Ellee Anak Nyanti. Prawn pond sludge as an organic fertilizer: Phase II. (Chapter 12, pp.189190). In K.T.Ng (Ed.). Selected student research projects of the $5^{\text {th }}$ Search for SEAMEO Young Scientists (SSYS 2006) Congress. 20 Penang, Malaysia: SEAMEO RECSAM, 2012.

[32] Muhammad Arif b. Ahmad and Muhammad Mursyid b. Hithayathulla. A composite organic filter to combat water pollution. (Chapter 10, pp.158-177). In K.T.Ng (Ed.). Selected student research projects of the $5^{\text {th }}$ Search for SEAMEO Young Scientists (SSYS 2006) Congress. 20 Penang: RECSAM, 2012.

[33] Ng, K.T. Selected student research projects of the $5^{\text {th }}$ Search for SEAMEO Young Scientists (SSYS 2006) Congress. 20 Penang, Malaysia: SEAMEO RECSAM, 2012. https://www.researchgate.net/profile/Khar_Ng/publication/292605229_1BookSSYS_2006-Compilev100712-Final/data/56af75ca08ae9f0ff7b25b2b/1BookSSYS-2006-Compile-v100712-Final.pdf

[34] Kim, P.L., Sim, J.T., Lee, S.M., and Ng, K.T. (Eds.). 101 Workshop for PBL facilitators programme handbook. (Compilation of presentation during PjBL Workshop Series No.1), 2007. Vision Academy (M) Sdn. Bhd. and CL Global Networks Sdn. Bhd.

[35] Ng, K.T. Presenting Project-based Learning (PjBL) Outcomes/Products; Sharing Insights of PBL via ICT; Refining and Improving PBL. In Kim, P.L., Sim, J.T., Lee, S.M., \& Ng, K.T. (Eds.), 101 Workshop for PBL facilitators programme handbook. (Compilation of presentation during PjBL Workshop Series No.1), 2007. Vision Academy (M) Sdn. Bhd. and CL Global Networks Sdn. Bhd.

[36] Ng, K.T. Assessing, evaluating and judging the outcomes of PBL. In Kim, P.L., Sim, J.T., Lee, S.M., \& Ng, K.T. (Eds.), 101 Workshop for PBL facilitators programme handbook. (Compilation of presentation during Project-based Learning Workshop Series No.1), 2007. Vision Academy (M) Sdn. Bhd.

[37] Mangao, D.D. \& K.T.Ng (2014). 'Search for SEAMEO Young Scientists' (SSYS) - RECSAM's initiative for promoting public science education: The way forward. Paper presented and published in the proceedings (indexed) of International Conference on Science Education 2012. Springer, Berlin, Heidelberg. Pp.45-56. 
[38] Wahid Y., Dede Iyan, S., Davi, A.A., Dava, A.A. and Ng, K.T. Learning mathematical concepts contextually supported by digital tool and e-platform. Presentation compiled in refereed Proceedings of ICRTSTMSD-2018, August 4-5, 2018 at Kuta Central Park Hotel, Bali, Indonesia.

[39] Chin, C.K., Hairiah, M., Miyadera, R., Ng, K.T., Ch'ng, Y.S. and Promising, N. Promoting education for sustainable development in teacher education integrating blended learning and digital tools: An evaluation with exemplary cases. In Eurasia Journal of Mathematics, Science and Technology Education. 15(1), em.1653.

[40] MoEYS Cambodia. Education Sector Performance Report 2004; UNESCO 2015, Education for All 2015 national review report. Ministry of Education, Youth and Sport (MoEYS), Kingdom of Cambodia, 2004.

[41] DFAT. Basic education: Practitioner level. Australian Government Department of Foreign Affairs and Trade (DFAT). https://www.dfat.gov.au/sites/default/files/basic-education-practitioner-level.docx

[42] Ng, K.T. Development of transdisciplinary models to manage knowledge, skills and innovation processes integrating technology with reflective practices. (Editor's choice). International Journal of Computer Applications (IJCA) (0975-8887) Scholarly peer-reviewed research publishing journal. No.2. pp.1-9.

[43] UNICEF. Basic education and gender equality: Quality of education. UNICEF, 2010. Retrieved 18 September 2017, https://www.unicef.org/education/index quality.html

[44] Pang, Y.J, Chuan TC, Ahmad SS, Thoe NK. Promoting Students' Interest in STEM Education through Robotics Competition-based Learning: Case Exemplars and the Way Forward.

[45] Pang, Y.J, Hussin H, Tay CC, Ahmad SS. Robotics Competition-Based Learning For 21st Century STEM Education. Journal of Human Capital Development (JHCD). 2019 Jan 1;12(1):83-100.

[46] Pang, Y.J, Hanipah H, Sharifah SS. Integrated Robotics STEM Curriculum Towards Industry 4.0. International Journal of Human and Technology Interaction (IJHaTI). 2018 Oct 25;2(2):17-24.

[47] Pang, Y.J, Chuan TC, Ahmad SS, Thoe NK. Developing Robotics Competition-based Learning Module: A Design and Development Research (DDR) Approach. In The Proceedings of the 5 the International Conference on Management, Engineering, Science, Social Science and Humanities 2020 Aug 14 (p. $63)$.

[48] Hussin H, Jiea PY, Rosly RN, Omar SR. Integrated 21st Century Science, Technology, Engineering, Mathematics (Stem) Education Through Robotics Project-Based Learning. Humanities \& Social Sciences Reviews. 2019 Mar 19;7(2):204-11.

[49] Bermúdez A, Casado R, Fernández G, Guijarro M, Olivas P. Drone challenge: A platform for promoting programming and robotics skills in K-12 education. International Journal of Advanced Robotic Systems. 2019 Jan 4;16(1):1729881418820425.

[50] Uluyol Ç, Şahin S. Elementary school teachers' ICT use in the classroom and their motivators for using ICT. British Journal of Educational Technology. 2016 Jan;47(1):65-75. 